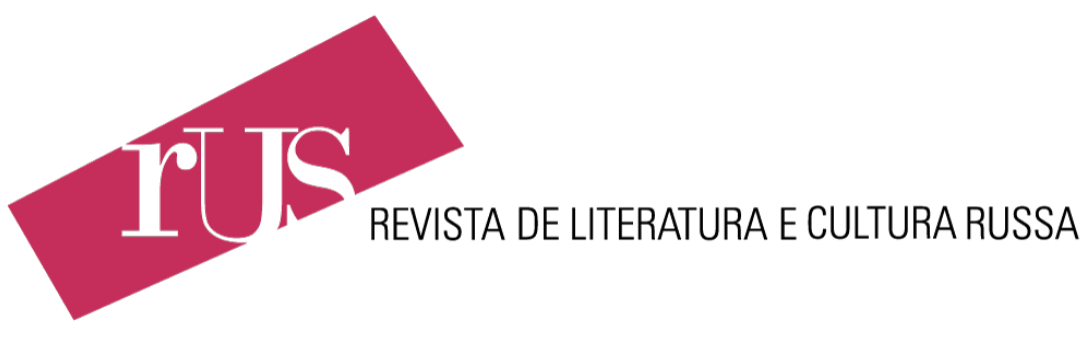

\title{
Interview with Michael Löwy (CNRS): Russian literature, philosophy and messianism
}

Autor: Jimmy Sudário Cabral Edição: RUS Vol. 12. № 18

Data: Abril de 2021 


\section{Interview with Michael Löwy (CNRS): Russian literature, philosophy and messianism}

Jimmy Sudário Cabral*

* Professor no Departamento e no Programa de Pós-Graduação em Ciência da Religião da Universidade Federal de Juiz de Fora. Coordenador do Núcleo de Estudos da Religião em Dostoiévski e Tolstói, Nerdt. htps://www.ufjf.br/nerdt/; E-mail: sudarioc@hotmail.com; https://orcid.org/0000-00016598-0554

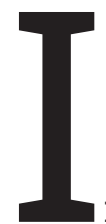

n the history of the Dostoevsky's and Tolstoy's reception in modern philosophical thought, a philosophical tradition of German-Jewish origin has a prominent role. Product of a singular "spiritual synthesis", as observed by Michael Löwy, the thought of Franz Kafka, George Lukács, Ernst Bloch, and Walter Benjamin has appeared in modern times as the sign of messianic claim for a libertarian, radical, and revolutionary socialism. ${ }^{1}$ Bearing in common the experience of not being reconciled with the world and history, ${ }^{2}$ this generation of intellectuals from Central Europe had "Jewish messianism" and "German romanticism" as privileged sources of their worldview. $^{3}$ The religious concept of redemption and the political

1 LÖWY, M. Redemption and Utopia: Jewish Libertarian Thought in Central Europe. A Study in Elective Affinity. London/New York: Verso, 2017.

2 BOURETZ, P. Témoins du futur. Philosophie et messianisme. Paris: Éditions Gallimard, 2003. p. 18.

3 LÖWY, M. Redemption and Utopia: Jewish Libertarian Thought in Central Europe. A Study in Elective Affinity. London/New York: Verso, 2017. 
notion of libertarian utopia were combined in the trajectory of this German-Jewish intelligentsia that promoted an unprecedented reconfiguration of philosophical thought. It is wellknown that the works of Dostoevsky and Tolstoy traverse the messianic and utopian imagery of this generation of revolutionary intellectuals and, as professor Michael Löwy assertively stated, "the utopian Bloch finds in Dostoevsky elements that legitimize The Principle of Hope: Aliocha Karamazov would be a precursor to the 'religious kingdom of justice'...". Such an observation is at the heart of a critical fortune accumulated in the works of Löwy and opens paths of analysis that have yet to be made in relation to the reception of Russian literature in modern Jewish philosophy.

Michael Löwy is director of research at the Centre national de la recherche scientifique (CNRS-Paris) and is one of the most significant and creative intellectuals of today. The Marxist philosopher's work offers a rare intertwining of socialism and surrealism, and establishes a meticulous approximation between philosophy and literature. ${ }^{4}$ The acuity with which Löwy interprets the German-Jewish messianism and romanticism, the tragic negativity and the ethical and human claims brought to light by such a tradition presents us with a revolutionary and libertarian state of being that only has equivalents in the utopian-messianic glimpses we find in the great Russian novels. The concept of "Romantic anti-capitalism", which made it possible to read the romantic tradition in a revolutionary way, can be interpreted as the fil rouge that connects the world of Tolstoy and Dostoevsky to the messianic utopianism of modern Judaism. The reception of Russian literature in the philosophical thought of the 20th century was complex and polyphonic, and the example of Dostoevsky, a thinker who, for Löwy, "is clearly situated on the grounds of

4 Among his works, we highlight Redemption and Utopia: Jewish Libertarian Thought in Central Europe; Georg Lukács: from Romanticism to Bolchevism, London, Verso, 1981; The War of Gods: Religion and Politics in Latin America, London, Verso, 1996; Romanticism against the Tide of Modernity (with Robert Sayre), Durham, Duke University Press, 2001; Morning Star: Surrealism, Marxism, Anarchism, Situationism, Utopia, University of Texas Press, 2009; Franz Kafka, rêveur insoumis, Paris, Editions Stock, 2004; Fire Alarm. Reading Walter Benjamin's 'On the Concept of History', London, Verso, 2005. 
the romantic world-view", becomes significantly emblematic. Although a conservative romanticism has found in the author of The Brothers Karamazov elements that could legitimize the nationalist desire for roots arising from a conservative tradition (Moeller van den Bruck, Goebbels, Heidegger), the utopian-revolutionary interpretation of the Russian writer made by "Jews of German culture" is among the most creative pages of modern philosophy. The set of analyses offered by Michael Löwy on the Jewish and neo-romantic tradition represented by authors such as Kafka, Lukács, Bloch, and Benjamin is an essential material for those who seek to better understand the reception and influence of Russian literature, especially Dostoevsky and Tolstoy, in the philosophical constellation of Judaism in the first half of the 20th century. The elective approximation carried out by the Franco-Brazilian philosopher between the "spiritual culture" expressed in the works of Dostoevsky and Tolstoy and the historical condition of Jewish intellectuals in Central Europe appears here as an essential element.

An anecdote told by Emmanuel Levinas during an interview with François Poirie reveals that, during the visit of an Israeli from Eastern Europe to his home, the visitor noticed the complete works of Pushkin on the bookshelves and stated: "One immediately sees that we are in a Jewish house". ${ }^{5}$ In the interview we present here and, above all, in the greatness of Michael Löwy's works, we can find fundamental clues to interpret the spiritual proximity between a Central European Jewish tradition and the great Russian literature. This "attractio electiva", coming from a neo-romantic Jewish intelligentsia in relation to the theological and utopian residues that are embodied in the works of Dostoevsky and Tolstoy (residues that may be essentially Jewish), can be interpreted as the most explosive element of modern philosophical messianism.

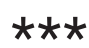

5 POIRIÉ, François. Emmanuel Lévinas : Essai et entretiens. Paris: Babel, 3006, p. 64 
Jimmy Sudário Cabral (RUS): I would like to start with a question that philosopher Ernst Bloch addressed to you in 1974, during an interview you were conducting: ${ }^{6}$ Why did Dostoevsky and Tolstoy exercise and still exercise such a strong influence on modern and Western intellectuals?

Michael Löwy (ML): It is difficult, if not impossible, to answer this question... The influence is different in each time and country. Since these are great writers whose work touches on essential questions of the human condition, it is not surprising that they have such influence. Undoubtedly, the fact that they are Russian authors, inspired by a spiritual culture very different from that of Western European civilization, allows them to take a distance in relation to the latter, which contributed to the interest they aroused.

RUS: In his memories of Max Weber, Paul Honigsheim ${ }^{7}$ showed how Tolstoy and Dostoevsky were present in the imaginary and discussions about ethics, philosophy, and politics in the Max Weber circle. Introducing Weber's confrontations with the radical ethics of late Tolstoy, Honigsheim states that Weber, in his germinal article, "Two Ethics (Zwei Moralen)", considered that only a man who lived like Tolstoy did could invoke the Sermon on the Mount and proclaim the merits of pacifism and disarmament. Honigsheim also notes that, even after the war, Weber felt the need to position himself more clearly concerning Tolstoy's ethics. Could you comment on that?

ML: Heidelberg's Max Weber circle was, according to Honigsheim's testimony, a space where many of the participants-writers, philosophers, sociologists-shared the romantic critique of modern civilization. Interest in the two Russian writers certainly has to do with this dissenting perspective.

6 LÖWY, Michael. Pour une sociologie des intellectuels révolutionnaires. L'évolution politique de Lukács, 1909-1929. pp. 318-330.

7 HONIGSHEIM, Paul. The Unknown Max Weber. New Brunswick, New Jersey: Transaction Publishers, 2003. 
Max Weber did share this criticism to a certain extent, as some moments of his work testify (e.g., the final pages of Protestant Ethics). On the other hand, the discussion with Tolstoy's ideas of corresponds to his conviction that we inevitably live, in modernity, in a universe of "war of Gods" (Kampf der Götter): what for some is an absolute good-e.g., "the defense of the homeland"-for others is unacceptable because it is opposed to the Christian imperative of peace and love of neighbor (Tolstoy). Weber disagrees with Tolstoy but respects his uncompromising commitment to Christ's Sermon on the Mount. I don't know if he changed his mind after the war, considering how the conflict as a disaster and the immense number of useless victims.

RUS: In an interview entitled Religious Immoralism and Political Immoralism, Gershom Scholem stated that the Kibbutz movement was traversed by a strong religious élan and that it could be considered a Jewish version of the Tolstoian ideal. ${ }^{8}$ Could you comment on this statement and talk a little about Tolstoy's reception on the horizon of European intellectuals in the 20th century?

ML: I have the impression that the religious dimension of the kibbutz has more to do with the Jewish veteran-testamentary tradition-the social doctrine of the prophets, messianismthan with Tolstoy's Christian religiosity. What Kibbutz took from Tolstoy was more the cult of peasant life, the material and spiritual relationship with the land, the austere simplicity of the peasantry (in contrast to the corruption of city life). I cannot comment on Tolstoy's reception in Europe, which is too broad a topic...

RUS: In your approach to Romanticism, we learned how this is a complex concept and is often associated with a conservative philosophical and political tradition. Dostoevsky's re-

8 SCHOLEM, Gershom. Les Cahiers de I'Herne. Éditions de l'Herne, 2009. pp. $85-91$ 
ception in German reactionary romanticism is, in this sense, very emblematic. We can quote here Joseph Goebbels's novel Michael: Pages from a German Destiny, in which we read: "We believe in Dostoevsky as our fathers believed in Christ". ${ }^{9}$ Could you comment on the reception of Dostoevsky's works in the context of German romantic conservatism?

ML: Dostoevsky's work is clearly situated on the grounds of the romantic world-view, that is, on the cultural critique of modern Western (capitalist) civilization in the name of past values. It is a deeply ambivalent thought, allowing for very different and even contradictory readings. In Germany, several reactionary thinkers referred to Dostoevsky to develop a counter-revolutionary ideology. This was the case of Moeller van den Bruck, a theorist of the conservative revolution, author of a book about Dostoevsky that had a lot of impact, and, more superficially, of others, like Mr. Goebbels. This did not prevent leftist thinkers, revolutionaries, socialists, and communists from referring to Dostoevsky as well. It is the case of young Lukács, Ernst Bloch, Walter Benjamin. Not by chance, all of them were Jewish intellectuals.

RUS: In the context of your research on the thought of G. Lukács, we observed the challenge of explaining the divergent interpretations of Dostoevsky's work carried out by the author of The Theory of The Novel throughout the 1930s, 1940s, and 1950 s of the 20th century. Could you comment on these oscillations in Lukács's thinking in relation to Dostoevsky's work?

ML: In my book with Robert Sayre, Romanticism against the Tide of Modernity, there is a chapter on Lukács that examines in detail this strange oscillation of the Hungarian philosopher in relation to the Russian writer. While the young Lukács proposes, particularly in The Theory of the Novel (1916), a utopian/revolutionary reading of Dostoevsky, in the late 1920s he

9 GOEBBELS, Joseph. Michael: Ein deutsches Schicksal in Tagebuchblättern. Munich: Zentralverlag der NSDAP, 1942. p. 34. 
published an article that denounced the Russian writer as an expression of the reactionary character of anti-capitalist romanticism. This orientation continues throughout the 1930s, but at the beginning of World War II there was a new turn, with Dostoevsky once again being seen as a utopian figure. And so on... It is difficult to give a clear explanation of these turnarounds. It undoubtedly has to do with Lukács's more general attitude towards romantic anti-capitalism. Does it correspond to changes in the line of the communist movement? Frankly, I have no answer...

RUS: Ernst Bloch's formulation of a "collectivist religious kingdom of justice in the spirit of Dostoevsky" has elements that come close to the very concept of utopia that we find in Blochian thought. In Walter Benjamin's essay on The Idiot ${ }_{10}^{10}$ we find a different horizon, with a more pessimistic, tragic tone, and which perhaps discerned the existence of an unfathomable abyss in Dostoevsky's thought. Could you comment on the proximity and differences in Benjamin and Bloch's reading of Dostoevsky's work?

ML: Sorry, but I would have to carry out significant research to answer this question. Once again, we are faced with Dostoevsky's "polyvalence", whose work is both utopian and tragic. Perhaps this ambiguity is one of the reasons for the fascination that he exerts on European thinkers. The utopian Bloch finds in Dostoevsky elements that legitimize The Principle of Hope:11 Aliocha Karamazov would be a precursor to the "religious kingdom of justice". Walter Benjamin, adept at a "pessimism across the board" (see his 1929 article on surrealism), ${ }^{12}$ interprets the Russian writer as a tragic author.

10 BENJAMIN, Walter. Selected Writings, v. 1. Cambridge: Harvard University Press, 2002. p. 78.

11 BLOCH, Ernst. The Principle of Hope, 3-vol, The MIT Press, 1995.

12 BENJAMIN, Walter. Selected Writings, v. 2. Cambridge: Harvard University Press, 2005. p. 207. 
RUS: Heidegger's enthusiasm for Dostoevsky's works underscores the trajectory of this philosopher and marked his reflections on the concepts of "nihilism" and "rooting". We can mention here Heidegger's use of Dostoevsky's Pushkin Speech, ${ }^{13}$ in the conference On Nietzsche's Concept of "European Nihilism" (1949) ${ }^{14}$ and the quote from The Demons: "He who has no people has no God!", 15 in the Black Notebooks of 1939-1941. In a letter to his wife Elfriede, from July 1920, Heidegger eagerly recommended reading Dostoevsky's Political Writings and confessed that it was the author of The Brothers Karamazov who taught him the meaning of being "rooted in a soil". ${ }^{16} \mathrm{It}$ is known that Dostoevsky's Political Writings populated the philosophical imagery of the German conservative revolution and, therefore, it is not without surprise that we discovered, through Gershom Scholem, that Walter Benjamin considered them the most important political work of which he was aware in modern times. ${ }^{17}$ In view of the opposite trenches in which Benjamin and Heidegger found themselves, how would you interpret the reception of Dostoevsky's work by these two thinkers?

ML: I am not interested in Heidegger, so I could not answer this question. Regarding Benjamin, I answered the previous question. These "opposing trenches" once again confirm and illustrate the wonderfully ambivalent character of Dostoevsky's work. All these readings are essentially based on some aspect of this work, but are inevitably one-sided. Obviously, from an ethical and human point of view, I consider Benjamin's interpretation immensely superior to Heidegger's.

13 DOSTOEVSKY, Fyodor. Pushkin. In Russian Views of Pushkin's Eugene Onegin. Bloomington and Indianapolis: Indiana University Press, 1988. p. 56.

14 HEIDEGGER, Martin. Nietzsche. v. II. Rio de Janeiro: Forense Universitária, 2007. pp. 21-22.

15 HEIDEGGER, Martin. Reflexiones XII-XV. Cuadernos Negros, 1939-1941. Editorial Trotta, 2019. p. 108.

16 HEIDEGGER, Martin. Alma mía! Cartas de Martin Heidegger a su mujer Elfide 1915-1970. Buenos Aires: Manantial, 2008. pp. 120-121.

17 Politischen Schriften appeared in 1907 by the publisher Piper. 
RUS: In his book on Franz Kafka, Max Brod informs us that the author of The Process read Gogol, Tolstoy, and Dostoevsky with enthusiasm and that, of the latter, he especially appreciated The Adolescent. Brod tells us that Kafka once read a passage of the book with exultation, "a passage about begging and getting rich". ${ }^{18}$ The idea of becoming a Rothschild, the absolute contradiction between alms and enrichment, the illusory relationship between money and freedom, and the link between capitalism, misery, and enslavement are central themes in The Adolescent and are close to Kafka's criticism of the effects of civilization. In view of the "radical negativity" that we find in both Dostoevsky and Kafka's work, could you tell us something about a possible "elective affinity" between the two authors?

ML: Another example of a Jewish intellectual who makes a libertarian reading of Dostoevsky... It seems to me that the elective affinity between the two has to do with the romantic world-view that both share. Both are critics of capitalist civilization, based on money, the obsessive search for enrichment, the enslavement of human beings by the apparatus. In Kafka, this romantic sensitivity takes on an anarchist coloration, not in the form of utopia, but of "radical negativity" in the face of the existing state of affairs. Dostoevsky broke with the revolutionary dreams of his youth, but his work has this dimension of radical criticism, which enchanted Franz Kafka.

RUS: In your book Pour une sociologie des intellectuels révolutionnaires (1976), you mention the claim of Ernst Bloch, who considered that at the origin of the romantic-revolutionary messianism lies an immemorial and underground tradition of mysticism and heresy. In the same direction, Theodor Adorno proposed a relationship between the messianism of Gershom Scholem and the underground-mystical tradition of Christian apocatastasis. For Adorno, becoming an object of anathema within Christianity, such a mystique deeply influenced

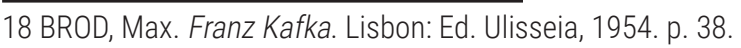


the Eastern Church and, later, became incarnate in the great modern Russian literature. ${ }^{19}$ Would it be possible to recognize a kind of influence of Russian literature on the rewriting of modern Jewish messianism?

ML: It is a good hypothesis, which deserves research. I am not sure whether Scholem, Benjamin or Ernst Bloch's messianism has to do with Christian mystique or Russian literature. It seems to me that, here, Jewish, veteran-testamentary or kabalistic sources are more relevant. The one who was most interested in Eastern religiosity, and in Dostoevsky in this context of mystical spirituality, was Georg Lukács, particularly in his unfinished manuscript on Dostoevsky, written in the years 1915-1918.

I will now propose a question that was not asked: Why is it that most-if not all-of the authors who propose a utopian, revolutionary, libertarian reading of Dostoevsky are Jews of German culture? It probably has to do with the semi-pariah condition of Jewish intellectuals in Central Europe, as well as with the adherence of many of them to the romantic view of the world. I tried to address these issues in my book Redemption and Utopia: Jewish Libertarian Thought in Central Europe.

19 ADORNO, Theodor. "Salut à Gershom Scholem Pour son 70e anniversaire". In SCHOLEM, Gershom. Les Cahiers de l'Herne. Éditions de l'Herne, 2009. p. 171-175. 


\section{Referências bibliográficas}

BENJAMIN, W. Escritos sobre mito e linguagem (1915-1921). São Paulo: Duas Cidades/Ed. 34, 2013. p. 75-80.

BENJAMIN, W. O surrealismo. In: Obras Escolhidas I - Magia e técnica, arte e política. São Paulo: Ed. Brasiliense, 2012. p. 21-35. BLOCH, E. O princípio esperança. Rio de Janeiro: Contraponto/ Uerj, tomo 1, 2005; tomo 2-3, 2006.

BOURETZ, P. Témoins du futur. Philosophie et messianisme. Paris: Éditions Gallimard, 2003. p. 18.

DOSTOIËVSKI, F. Púchkin. In: GOMIDE, B. Antologia do pensamento crítico russo (1802-1901). São Paulo: Ed. 34, 2013. p. 405423.

GOEBBELS, J. Michael: Ein deutsches Schicksal in Tagebuchblättern. München: Zentralverlag der NSDAP, 1942. p. 34.

HEIDEGGER, M. Nietzsche. v. II. Rio de Janeiro: Forense Universitária, 2007. p. 21-22.

HEIDEGGER, M. Reflexiones XII-XV. Cuadernos Negros, 19391941. Editorial Trotta, 2019. p. 108.

HEIDEGGER, M. Alma mía! Cartas de Martin Heidegger a su mujer Elfide 1915-1970. Buenos Aires: Manantial, 2008. p. 120121.

HONINGSHEIM, P. The Unknown Max Weber. New Brunswick, New Jersey: Transaction Publishers, 2003.

LÖWY, M.; SAYRE, R. Revolta e melancolia: o romantismo na contracorrente da Modernidade. São Paulo: Boitempo, 2020.

LÖWY, M. Pour une sociologie des intellectuels révolutionnaires. L'évolution politique de Lukacs, 1909-1929. p. 318-330.

LÖWY, M. Redenção e utopia: o judaísmo libertário na Europa Central. São Paulo: Perspectiva, 2020.

LÖWY, M. Romantismo e messianismo: ensaios sobre Lukács e Benjamin (São Paulo: Perspectiva, 2012

LÖWY, M. Franz Kafka: sonhador insubmisso. (Azougue Editorial, 2005) 
LÖWY, M. Walter Benjamín: aviso de incêndio. Uma leitura das teses 'Sobre o conceito de História'(São Paulo: Boitempo, 2005). LÖWY, M. Revolta e melancolia: o romantismo na contramão da modernidade (Petrópolis: Vozes, 1995)

LÖWY, M. A evolução política de Lukács: 1909-1929 (São Paulo: Cortez, 1998)

LUKÁCS, G. A teoria do romance. Um ensaio histórico-filosófico sobre as formas da grande épica. São Paulo: Duas Cidades/ Ed. 34, 2000.

POIRIÉ, F. Emmanuel Levinas: ensaio e entrevistas. São Paulo: Perspectiva, 2007. p. SCHOLEM, G. Les Cahiers de l'Herne. Éditions de l'Herne, 2009. p. 85-91.

Recebido em: 25/02/2021

Aceito em: 11/03/2021

Publicado em abril de 2021 